\title{
Visões de cidade: fotografia das paisagens urbanas
}

\section{Raúl Yépez \\ COLLANTES}

\section{Resumo}

A pesquisa está relacionada com a temática sobre fotografia e cidade. Estuda imagens produzidas por três fotógrafos modernos (Eugène Atget, Brassaï, Henri Cartier-Bresson) e três fotógrafos contemporâneos (Franco Fontana, Antônio Saggese, Cássio Campos Vasconcellos) que têm incluído nas suas obras, uma visão particular das paisagens urbanas. Mestres da imagem escrita com luz exploram neste campo, aspectos relacionados com a procura de acontecimentos passageiros na cidade. Eles fornecem com suas propostas, a matéria prima da estrutura conceptual da presente investigação, que utiliza os estilos fotográficos, a linguagem da fotografia e as teorias da cultura visual, para ensaiar uma interpretação formal e crítica das suas imagens baseada na produção de significados. Além disso, o trabalho incorpora mais uma visão de cidade, relacionada com a pesquisa de campo do autor, que explora detalhes dos efeitos visuais efêmeros no cenário citadino, com fotos de sombras, reflexos, texturas, fatos do tempo atmosférico (chuva, vento) e da temporalidade (recuperação, deterioração).

Palavras-chave: Fotografia, fotógrafos, paisagens urbanas. 